\title{
THE DECOMPOSITION OF L-(+)-TARTARATE BY THE MICROORGANISMS
}

\author{
BY MASAYASU NOMURA AND KIN-ICHIRO SAKAGUCHI \\ The Institute of Applied Microbiology, University of Tokyo \\ Received for publication August 30, 1954
}

$\mathrm{L}-(+)$-Tartaric acid is widely distributed among the higher plants, and many microorganisms are known to decompose it. In view of the significant role of the organic acids present in plants in the intermediary metabolism, it might be supposed that tartaric acid also plays some role in the metabolism of living cells, especially in plants or microorganisms. There have been several reports on the microbiological breakdown of this acid ${ }^{(14,19,21,24)}$, but they were only qualitative or taxonomical studies and at present the metabolic behavior of this acid is scarcely known.

Therefore the present study was undertaken in order to clarify these problems. Pseudomonas incognita was used in this study. It was isolated from soil, and investigated with reference to aerobic and anaerobic decomposition of tartarate. Some results obtained will be reported in this paper.

\section{EXPERIMENTAL METHODS}

1. Bacterium used: Several strains which readily decompose tartarate were isolated from various sources by the enrichment technique ${ }^{(16)}$ and one of them, isolated from the soil and identified as Pseudomonas incognita(16,17), was used in this study.

This strain, Pseudomonas incognita strain $3 L$, was usually grown in the tartarate-bouillon medium $\left(\mathrm{NH}_{4}\right.$-tartarate $1.2 \%$, meat extract $0.8 \%$, peptone $0.5 \%, \mathrm{NaCl} 0.5 \%, \mathrm{pH}=6.0$ ) at $30^{\circ}$ for 40 to $48 \mathrm{hrs}$. by stationary culture (anaerobically grown cell) or for 16 to $24 \mathrm{hrs}$. at $25^{\circ} \mathrm{C}$ by shaking culture (aerobically grown cell). After harvesting, the cells were washed with $0.2 \% \mathrm{KCl}$ solution, resuspended in $0.2 \% \mathrm{KCl}$ and used as resting cell suspensions. When dried cell preparations were used, they were prepared by vacuum-drying the washed dense cell suspension over $\mathrm{CaCl}_{2}$.

2. Manometric and chemical methods: $\mathrm{O}_{2}$ consumption and $\mathrm{CO}_{2}$ evolution were followed in the conventional Warburg apparatus at $30^{\circ} \mathrm{C}$ with air as the gas phase for the aerobic experiment or with $\mathrm{N}_{2}$ for the anaerobic experiment.

DL-Phosphoglycerate was prepared by Kiessling's method ${ }^{(9)}$. D-(-)Phosphoglycerate prepared with yeast was kindly supplied by Mr. K. Omura. Phosphotartarate was prepared by the method of Neuberg et al. from the L-(+)-tartarate and phosphorus oxychloride ${ }^{(15)}$. 
Tartarate ${ }^{(13)}$, inorganic phosphate ${ }^{(6)}$, acetoin ${ }^{(26)}$, and diacetyl ${ }^{(26)}$ were determined colorimetrically. Succinate ${ }^{(23)}$ and pyruvate ${ }^{(23)}$ were determined manometrically. D-(-)-Malate was also determined manometrically by the decarboxylation method using the resting cell of malate adapted Lact. arabinosus.

Volatile acids were separated from the incubation medium by steam distillation. Formic acid was determined by the permanganate oxidation method. After the oxidation, the distillate was redistilled and acetic acid was determined by titration with alkali.

Paperchromatography of organic acids was performed by the method of Lugg et al. (1.1) and that of keto acids by the method of Cavallini et al. (5)

3. Measurements of radioactivity: Carbon dioxide evolved was absorbed in alkali, precipitated as $\mathrm{BaCO}_{3}$, dried and counted by the conventional Geiger-Müller counter with an end window. The counted data was corrected for self absorbtion.

Formic acid was degraded by permanganate oxidation and counted as $\mathrm{BaCO}_{3}$. Acetic acid was isolated as $\mathrm{Na}$ salt from the steam distillate after the removal of formic acid and counted as such.

Pure succinic acid was isolated from the reaction medium by ether extraction and decomposed by Van Slyke-Folch wet oxidation ${ }^{(4)}$ and counted as $\mathrm{BaCO}_{3}$. The specific activity of carboxyl carbon of succinate was obtained by degrading succinate to $\mathrm{CO}_{2}$ and lactic acid by the method of Foster et al. (7) The specific activity of methylene carbon was calculated by the difference between total specific activity and that of carboxyl carbon and also confirmed by measuring directly the 2,4-dinitrophenylhydrazone of acetaldehyde which was obtained from the non-carboxyl carbons of lactic acid by $\mathrm{KMnO}_{4}$ oxidation ${ }^{(8)}$.

Tartaric acid was isolated as acid potassium salt and degraded by the Sprinson's periodate oxidation method ${ }^{(20)}$ according to the following equation.

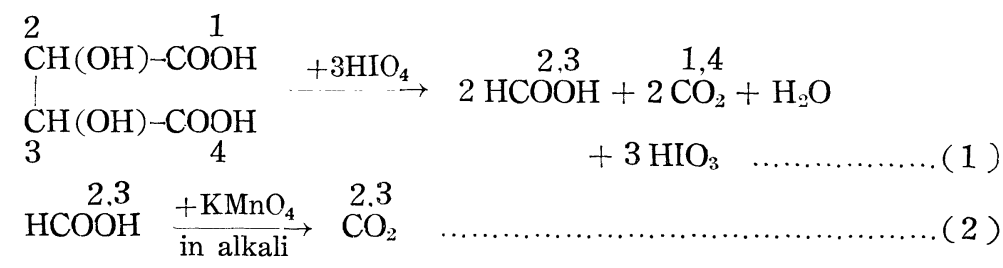

Carbon dioxide, evolved by reaction (1) and (2) corresponding to the carboxyl and $-\mathrm{CH}(\mathrm{OH})-$ carbons of tartarate respectively, was counted as $\mathrm{BaCO}_{3}$.

\section{EXPERIMENTAL RESULTS}

Part 1. Anaerobic decomposition of $\mathrm{L}-(+)$-tartarate.

1. Identification of the decomposition products(16).

The decomposition products of tartarate were examined using the 
resting cell suspension. The composition of the reaction mixture was as follows: $\mathrm{Na}-\mathrm{L}-(+)$-tartarate $\left(8.365 \mathrm{~g}\right.$ of free acid), $\mathrm{MgSO}_{4} \cdot 7 \mathrm{H}_{2} \mathrm{O} 0.4 \mathrm{~g}$, tap water containing $1.2 \mathrm{~g}$ dry weight of cells $100 \mathrm{ml}$., M/15 phosphate buffer $(\mathrm{pH}=7.0) 700 \mathrm{ml}$. Total volume $800 \mathrm{ml}$. After the incubation of $73 \mathrm{hrs}$. at $30^{\circ} \mathrm{C}$ the fermentation medium was analyzed. By the addition of 2,4dinitrophenylhydrazine to the acidified medium a very small amount of hydrazone, which was insoluble in alkali, was obtained, but owing to its small quantity it's identification could not be achieved. The distillate of the neutral distillation was examined for alcohol, acetone, diacetyl, and acetaldehyde, but none of these compounds were found. Acetic acid was isolated by acid-steam distillation and identified as $p$-bromphenacyl ester (m.p. $=82.5^{\circ}$, not depressed by mixing with a known sample of $p$-bromphenacyl ester) and also as the $\mathrm{Ag}$ salt (Calculated for $\mathrm{Ag}$ acetate, $\mathrm{Ag}$ $64.7 \%$; Found $64.6 \%$ ).

Formic acid was also detected by the calomel test in the acid-steam distillate, but its quantity was very small.

Succinic acid was isolated from the acidified medium by continuous ether extraction, recrystallized from water, and identified by the mixed melting point (m.p. $=183^{\circ}$ ).

Besides succinic acid and tartaric acid no other organic acid was found when tested with paperchromatography. Thus the main fermentation products were confirmed to be acetic acid and succinic acid.

\section{Balance study.}

The balance study on the anaerobic decomposition of tartarate was performed using the resting cell suspensions. From the results shown in Table 1, it was clearly established that anaerobic decomposition of tartarate by this organism is performed according to the following equation.

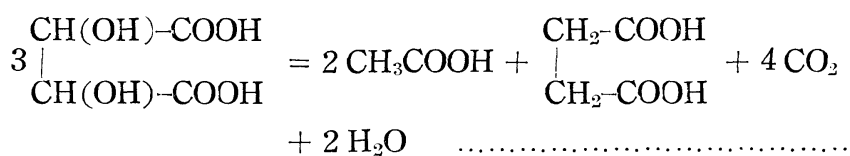

Table 1. The anaerobic decomposition of $\mathrm{L}-(+)$-tartarate.

Part 1.

\begin{tabular}{l|c|c|c}
\hline & \multicolumn{2}{|c|}{ Observed value } & \multirow{2}{*}{ Molar ratio } \\
\cline { 2 - 3 } & $\mathrm{mg}$ & $\mathrm{mM}$ & \\
\hline L-(+)-Tartaric acid consumed & 397 & 2.63 & 3 \\
Acetic acid formed & 103.7 & 1.73 & 1.97 \\
Succinic acid formed & 94.0 & 0.80 & 0.91 \\
\hline
\end{tabular}

Composition of the reaction mixture: Na-L- $(+)$-tartarate $(915 \mathrm{mg}$ as free acid), $\mathrm{MgSO}_{4} \cdot 7 \mathrm{H}_{2} \mathrm{O} 50 \mathrm{mg}$, cell suspension ( $250 \mathrm{mg}$ dry wt. of cells) $25 \mathrm{ml}, \mathrm{M} / 15$ phosphate buffer $(\mathrm{pH}=7.0) 75 \mathrm{ml}$. Total volume, $100 \mathrm{ml}$. Temp., $30^{\circ} \mathrm{C}$. Time, $37 \mathrm{hrs}$. Anaerobic condition was maintained by evacuation. 
Part 2.

\begin{tabular}{l|c|c}
\hline & Observed value & Molar ratio \\
\hline L-(+)-Tartaric acid consumed & $2.00 \mu \mathrm{M}$ & 3 \\
$\mathrm{CO}_{2}$ evolved & $2.58 \mu \mathrm{M}$ & 3.87 \\
\hline
\end{tabular}

Evolved $\mathrm{CO}_{2}$ was measured in Warburg's respirometer. Experimental conditions: Na-L- $(+)$-tartarate $\mathrm{M} / 950(2 \mu \mathrm{M})$, phosphate buffer $\mathrm{M} / 28.5(\mathrm{pH}=5.6)$, cell weight $18.3 \mathrm{mg}$, total volume $1.9 \mathrm{ml}$. Temp., $30^{\circ} \mathrm{C}$. Gas phase, $\mathrm{N}_{2}$. Time, $50 \mathrm{~min}$.

\section{Anaerobic decomposition of tartarate in the presence of radioactive bicarbonate $e^{(17)}$.}

As shown in the previous section, the anaerobic decomposition of tartarate is performed according to equation (3). In order to clarify the mechanism of this reaction, anaerobic decomposition of this acid by the resting cells was conducted in the presence of radioactive bicarbonate and the incorporation of $\mathrm{C}^{14} \mathrm{O}_{2}$ into various compounds was examined. The large Thunberg tube was used for the reaction vessel, and the composition of the reaction medium is listed in Table 2.

Table 2. Composition of the medium for the anaerobic decomposition of tartarate.

Main compartment Cell suspension* $20 \mathrm{ml}$. (285 mg dry wt.) $\mathrm{M} / 15$ phosphate buffer $(\mathrm{pH}=6.9) 15 \mathrm{ml}$.

Side arm $\mathrm{Na}$ tartarate- $\mathrm{MgSO}_{4}$ solution (tartarate $693 \mathrm{mg}$ as free acid, $\left.\mathrm{MgSC}_{4} \cdot 7 \mathrm{H}_{2} \mathrm{O} 20 \mathrm{mg}\right) 5 \mathrm{ml}$. $\mathrm{Na}_{2} \mathrm{C}^{14} \mathrm{O}_{3}$ in $\mathrm{N} / 10 \mathrm{NaOH} 0.5 \mathrm{ml}$. (Ca, 1,400,000 c.p.m.)

* Cells obtained by stationary culture in the tartarate-bouillon medium for 40 hours at $30^{\circ} \mathrm{C}$ were used.

Incubation was done at $30^{\circ} \mathrm{C}$ for 3 hours under anaerobic conditions. The analysis of the reaction medium was carried out by the methods already described and the results obtained are listed in Table 3 .

As shown in Table 3 very strong radioactivity was found in succinate and this radioactivity was found exclusively in carboxyl carbons. The specific activity of these carbons was 2.5 times as high as that of the final bicarbonate. Therefore this incorporation of $\mathrm{C}^{14}$ could not be explained by the mere exchange reaction between the succinic acid and $\mathrm{CO}_{2}$. So either the reaction, 
Table 3. Anaerobic decomposition of L-(+)-tartarate in the presence of radioactive bicarbonate.

\begin{tabular}{|c|c|c|c|c|}
\hline & \multicolumn{2}{|c|}{ Chemical data } & \multirow{2}{*}{$\begin{array}{c}\text { Isotopic data } \\
\text { specific activity } \\
\text { c.p.m. per } \mu \mathrm{M} \text { carbon }\end{array}$} & \multirow{2}{*}{ Total activity } \\
\hline & $\mathrm{mg}$ & $\mathrm{mM}$ & & \\
\hline Residual tartaric acid & 134.7 & 0.898 & 1.85 & 6,645 \\
\hline $\int^{-\mathrm{CH}-(\mathrm{OH})-}$ & & & 0 & 0 \\
\hline$\{-\mathrm{COOH}$ & & & 3.70 & 6,645 \\
\hline Tartaric acid consumed & 59.0 & 0.393 & & \\
\hline Acetic acid formed & 14.9 & 0.247 & 0 & 0 \\
\hline Succinic acid formed & 9.2 & 0.078 & 1565.6 & 488,000 \\
\hline $\int^{-\mathrm{CH}_{2}-}$ & & & 0 & 0 \\
\hline$\{-\mathrm{COOH}$ & & & 3397.0 & 529,900 \\
\hline $\mathrm{CO}_{2}$ formed & 27.8 & 0.632 & 1358.5 & 858,600 \\
\hline Formic acid formed & 1.8 & 0.040 & 860.6 & 34,400 \\
\hline Cell residue & & & & 7,610 \\
\hline
\end{tabular}

Carbon recovery $94.2 \%$.

$$
\text { Tartarate } \longrightarrow \mathrm{C} * \mathrm{O}_{2} \longrightarrow \text { Succinate }
$$

or, the reaction,

$$
\begin{array}{ll} 
& \mathrm{C}^{*} \mathrm{O}_{2} \\
1 \mathrm{~L} & \\
\text { Tartarate } \longrightarrow & \mathrm{X}^{*} \longrightarrow \text { Succinate }
\end{array}
$$

must be postulated (These correspond respectively to Scheme I and II in the following discussion). This compound $\mathrm{X}^{*}$ is the intermediate, well equilibrated with the bicarbonate in the medium, and considered to the oxalacetic acid. As expected, the organism was shown to have a high activity of oxalacetic acid decarboxylase both in the dried cell preparation $\left(\mathrm{QCO}_{2}=26.6\right.$ while $\mathrm{QCO}_{2}$ for tartarate is 8.4) and in the cell free extract (this extract was prepared by grinding the cells with alumina and extracting it with phosphate buffer $(\mathrm{M} / 50, \mathrm{pH}=7.0))$. Therefore the primary fixation reaction of the isotope may be the Wood-Werkman reaction.

Besides, formic acid formed in small amounts was found to have about the same specific activity as that of the final bicarbonate, while acetic acid showed no radioactivity. This latter observation clearly excluded the Thunberg-Wieland reaction, i.e. the formation of succinate according to the following equation.

$$
2 \mathrm{CH}_{3} \mathrm{COOH} \underset{+2 \mathrm{H}}{\stackrel{-2 \mathrm{H}}{\rightleftarrows}} \stackrel{\mathrm{CH}_{2}-\mathrm{COOH}}{\mathrm{CH}_{2}-\mathrm{COOH}}
$$

Residual tartaric acid showed weak activity and was labeled only in the carboxyl carbons.

These experimental results can well be explained either by Scheme I or II as follows: 
Scheme I.

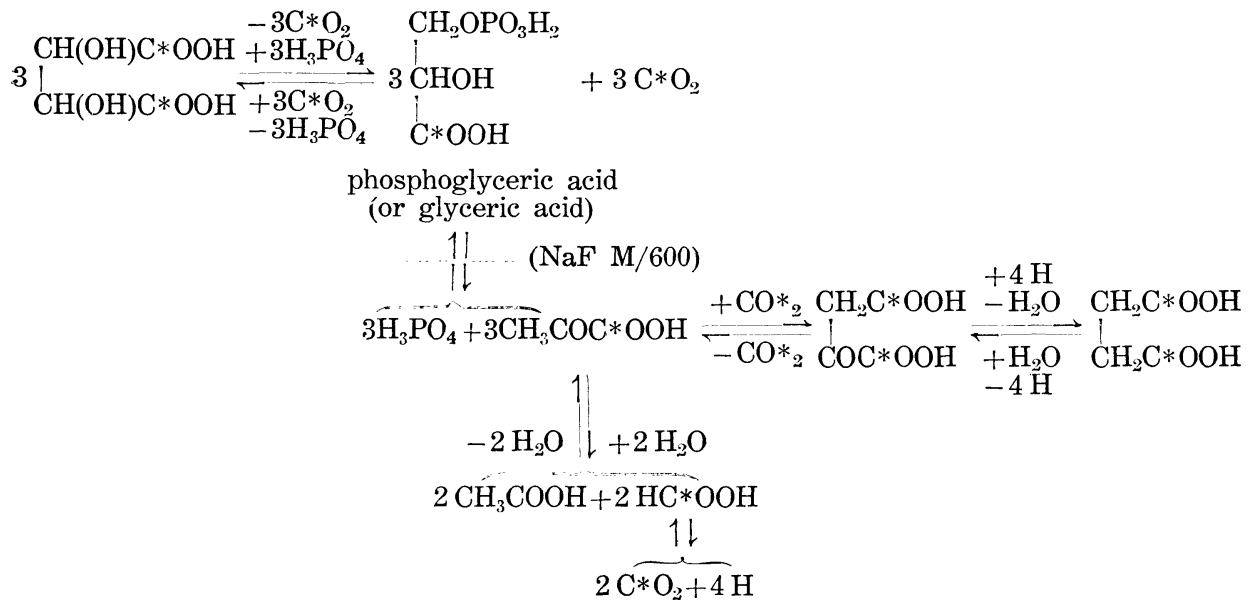

Scheme II.

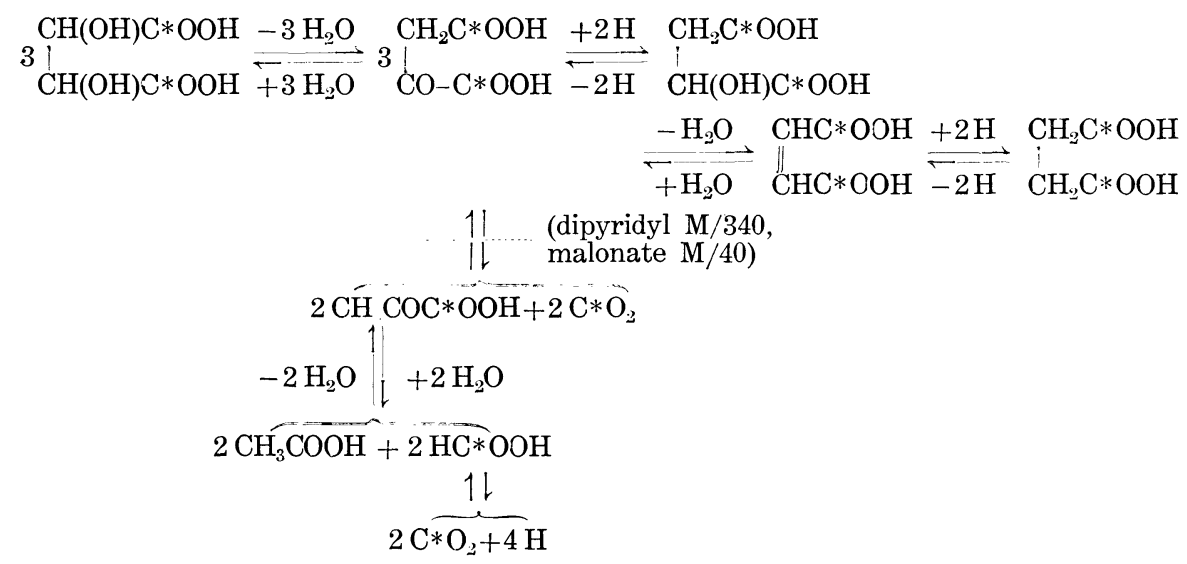

It is supposed that phosphorylated compounds or coenzyme bound compounds are true intermediates, but these active forms were omitted for simplicity. $\mathrm{C}^{*}=$ radioactive carbon.

Dotted lines represent the inhibition by the agents described (see text).

In the study of $\mathrm{CO}_{2}$ fixation in green plants using the $\mathrm{C}^{14}$ isotope it is known that in a very short time phosphoglyceric acid contains most of the radioactive element ${ }^{(3)}$. From these results Calvin et al, proposed a $\mathrm{C}_{4}$-dicarboxylic acid cycle ${ }^{(1)}$ or its modified cycle ${ }^{(2)}$ as a possible mechanism of the photosynthetic reaction. In these cycle the primary fixation reaction of $\mathrm{CO}_{2}$ are $\mathrm{C}_{2}+\mathrm{C}_{1}=\mathrm{C}_{3}$ (Phosphoglyceric acid) and $\mathrm{C}_{3}+\mathrm{C}_{1}=\mathrm{C}_{4}$. In Scheme $\mathrm{I}$, as shown above, the formation of phosphoglycerate by the decarboxylation of the tartarate was proposed as the first reaction of the decomposition 
of tartarate, and since $\mathrm{C}^{\mathbf{1 4}}$ incorporation into the carboxyl carbons of tartarate, as demonstrated experimentally, shows the reversibility of this reaction, tartarate seems to correspond to the "active $\mathrm{C}_{4}$ compound" of the Calvin-Benson cycle. This consideration, together with the fact that tartaric acid is widely distributed in the plants, makes Scheme I very attractive. But the various experimental results excluded the possibility of Scheme I as the main path of the decomposition of tartarate and supported the occurence of Scheme II. These experimental approaches will be described in the following section.

4. Examination of phosphoglycerate and oxalacetate as possible intermediates ${ }^{(18)}$.

a) Anaerobic decomposition of $D-(-)$-phosphoglycerate, DL-phosphoglycerate, and DL-glycerate.

Using resting cell suspension, we investigated anaerobic decomposition of $\mathrm{D}-(-)$-phosphoglycerate, which was considered as a possible intermediate in Scheme I, and also of DL-phosphoglycerate and DL-glycerate manometrically either in the presence of tartarate or in its absence (Table 4).

The results presented in Table 4 show that DL-phosphoglycerate and DL-glycerate were hardly decomposed by this organism, and that DLphosphoglycerate inhibited the decomposition of tartarate considerably and DL-glycerate a little. Whether these inhibitions are due to the presence of unnatural $\mathrm{L}$ form or not is unknown. On the other hand, $\mathrm{D}-(-)$ phosphoglycerate was decomposed at an appreciable rate, though this rate is still small compared to the rate of $\mathrm{CO}_{2}$ production from tartarate, and no inhibition was observed in this case. Moreover, while DL phospho-

Table 4. Anaerobic decomposition of DL-phosphoglycerate, D-(-)phosphoglycerate and DL-glycerate.

\begin{tabular}{|c|c|c|c|c|}
\hline $\begin{array}{c}\text { Exptl. } \\
\text { No. }\end{array}$ & $\begin{array}{c}\text { Time of } \\
\text { incubation } \\
\text { min. }\end{array}$ & Substrate added & $\underset{\mu \mathrm{l}}{\mathrm{CO}_{2}}$ evolved & $\begin{array}{c}\text { Inhibition } \\
\%\end{array}$ \\
\hline 1 & 50 & $\begin{array}{l}\text { Tartarate } 4 \mu \mathrm{M} \\
\text { DL-Phosphoglycerate } 4.3 \mu \mathrm{M} \\
\text { Tartarate } 4 \mu \mathrm{M}+ \\
\text { DL-Phosphoglycerate } 4.3 \mu \mathrm{M}\end{array}$ & $\begin{array}{c}39.8 \\
0 \\
18.0\end{array}$ & $\begin{array}{l}- \\
- \\
52.7\end{array}$ \\
\hline 2 & 170 & DL-Phosphoglycerate $8.1 \mu \mathrm{M}$ & 5.0 & 一 \\
\hline 3 & 140 & $\begin{array}{l}\text { Tartarate } 4 \mu \mathrm{M} \\
\text { D-(-)-Phosphoglycerate } 5 \mu \mathrm{M} \\
\text { Tartarate } 4 \mu \mathrm{M}+ \\
\text { D-(-)-Phosphoglycerate } 5 \mu \mathrm{M}\end{array}$ & $\begin{array}{r}81.5 \\
20.1 \\
103.9\end{array}$ & $\begin{array}{l}- \\
- \\
0\end{array}$ \\
\hline 4 & 95 & $\begin{array}{l}\text { Tartarate } 10 \mu \mathrm{M} \\
\text { DL-Glycerate } 8 \mu \mathrm{M} \\
\text { Tartarate } 10 \mu \mathrm{M}+ \\
\text { DL-Glycerate } 8 \mu \mathrm{M}\end{array}$ & $\begin{array}{r}88.1 \\
3.4 \\
75.1\end{array}$ & $\begin{array}{c}- \\
18.6\end{array}$ \\
\hline
\end{tabular}

Cells used: Expt. 1 and 2, 6.3 mg dry weight, Expt. 3, $8.9 \mathrm{mg}$. Expt. 4, $4.2 \mathrm{mg}$. 
glycerate was not decomposed by the dried cell preparation, $\mathrm{D}(-)$-phosphoglycerate was decomposed at a rate similar to that of the resting cell.

The observed slow rate of metabolism of DL-glycerate might be due to the permeability effect of the cell membrane. However, in view of the fact that $\mathrm{D}-(-)$ phosphoglycerate, which may have more difficulty in penetrating the cell membrane than DL-glycerate, is metabolized at an appreciable rate, it seems likely that DL-glycerate must be phosphorylated to phosphoglycerate at the first step, and owing to the limited rate of this phosphorylation step, the slow rate of metabolism of this acid was observed. Therefore $\mathrm{D}-(-)$ - phosphoglycerate was considered to be the most possible $\mathrm{C}_{3}$ acid proposed in Scheme I, and the metabolic behavior of this acid was examined in the following experiments.

b) Quantitative studies on the desomposition of $D-(-)$-phosphoglycerate.

Scheme I assumes that tartarate is tirst decarboxylated to $\mathrm{C}_{3}$ acid (possibly phosphoglyceric acid), and subsequently succinic acid is formed by the fixation of $\mathrm{CO}_{2}$ into pyruvate derived from this $\mathrm{C}_{3}$ acid.

Therefore, if in fact tartarate is decomposed according to Scheme I, the possibility of net $\mathrm{CO}_{2}$ fixation yielding succinate may be great when phosphoglycerate is added as substrate and the following reaction sequence may be observed.

3 phosphoglycerate $=3$ pyruvate $+3 \mathrm{H}_{3} \mathrm{PO}_{4}$

2 pyruvate $+2 \mathrm{H}_{2} \mathrm{O}=2$ acetate $+2 \mathrm{CO}_{2}+4 \mathrm{H}$

$$
\text { pyruvate }+\mathrm{CO}_{2}+4 \mathrm{H}=\text { succinate }+\mathrm{H}_{2} \mathrm{O}
$$

Sum: 3 phosphoglycerate $+\mathrm{H}_{2} \mathrm{O}=2$ acetate $+\mathrm{CO}_{2}+3 \mathrm{H}_{3} \mathrm{PO}_{4}$

According to equation (7), the formation of $1 / 3$ molecule of $\mathrm{CO}_{2}$ is expected per molecule of phosphoglycerate metabolized. But the experimental results (Table 5) showed that about 1 molecule of $\mathrm{CO}_{2}$ was evolved per molecule of phosphoglycerate consumed. Since in this experiment the consumption of phosphoglycerate was determined by the measurement of the increase of inorganic phosphate, besides reaction (7) the following reaction due to phosphatase action

phosphoglycerate $\longrightarrow$ glycerate + phosphate

might contribute to the increase of inorganic phosphate and therefore the

Table 5. The Decomposition of D-(-)-phosphoglycerate.

\begin{tabular}{c|c|c|c|c|c}
\hline $\begin{array}{c}\text { Exptl. } \\
\text { No. }\end{array}$ & $\begin{array}{c}\text { Phospho- } \\
\text { glycerate } \\
\text { added }(\mu \mathrm{M})\end{array}$ & $\begin{array}{c}\text { Time of } \\
\text { incubation }\end{array}$ & $\begin{array}{c}\mathrm{CO}_{2} \text { evolved } \\
(\mu \mathrm{M})\end{array}$ & $\begin{array}{c}\text { Increase of } \\
\text { inorg. } P \\
(\mu \mathrm{M})\end{array}$ & $\begin{array}{c}\mu \mathrm{M} \Delta \mathrm{CO}_{2} \\
\mu \mathrm{M} \Delta P\end{array}$ \\
\hline 1 & 10 & 240 & 1.80 & 1.75 & 1.03 \\
2 & 8 & 175 & 0.91 & 0.785 & 1.16 \\
\hline
\end{tabular}

Each flask contained cells $(6.9 \mathrm{mg}$ dry weight in experiment 1 and $5.8 \mathrm{mg}$ in experiment 2), M/150 phosphate buffer $(\mathrm{pH}=5.4) \quad 0.5 \mathrm{ml}$. and water. Final volume; $1.8 \mathrm{ml}$. in experiment 1 , and $2.0 \mathrm{ml}$. in experiment 2 . temp.; $30^{\circ} \mathrm{C}$. Gas phase; $\mathrm{N}_{2}$. 
true amount of $\mathrm{CO}_{2}$ formation per molecule of phosphoglycerate metabolized may be greater than the figures shown in the last column of Table 5 .

Therefore, it is clear that the $\mathrm{CO}_{2}$ fixation reaction according to equation (7) was not the main reaction. Of course the intermediate compound does not necessarily follow the same metabolic course as the parent substance, but in this case, from the thermodynamic point of view ${ }^{(18)}$, the $\mathrm{CO}_{2}$ fixation reaction according to Scheme I may be performed more easily when phosphoglycerate rather than tartarate is the substrate. Therefore this experimental result makes Scheme I unlikely.

c) The effect of $\mathrm{NaF}$ on the anaerobic decomposition of tartarate and $D-(-)$-phosphoglycerate.

It is well known that enolase which catalyzes reaction (8) is easily inhibited by $\mathrm{NaF}$ and consequently phosphoglycerate accumulates in a culture of bacteria as well as in yeast and animal cells.

$$
\mathrm{D} \cdot(-) \text {-phosphoglycerate }=\text { phosphopyruvate }+\mathrm{H}_{2} \mathrm{O}
$$

If the decomposition of phosphoglycerate by $P$ s. incognita is also catalyzed by enzyme enolase, this decomposition will be inhibited by $\mathrm{NaF}$. As expected, in the presence of $\mathrm{M} / 600 \mathrm{NaF}$, both $\mathrm{CO}_{2}$ production and inorganic phosphate release from phosphogiycerate were completely inhibited (Table 6). Therefore, if the decomposition of tartarate follows Scheme I which presupposed phosphoglycerate as an intermediate, the decomposition of tartarate should also be inhibited by NaF. But as shown in Table 6, no inhibition was observed in the presence of the same concentration of $\mathrm{NaF}$ and no phosphoglycerate was accumulated even when the tartarate decomposition was partially inhibited by the higher concentration of $\mathrm{NaF}$. Therefore phosphogiycerate was excluded as a possible intermediate.

Table 6. Inhibition of the anaerobic decomposition of tartarate and $\mathrm{D}-(-)$-phosphoglycerate by $\mathrm{NaF}$.

\begin{tabular}{|c|c|c|c|c|c|c|}
\hline $\begin{array}{c}\text { Exptl. } \\
\text { No. }\end{array}$ & $\begin{array}{l}\text { Time of } \\
\text { incubation } \\
\text { (min.) }\end{array}$ & Substrate & $\begin{array}{l}\mathrm{NaF} \\
\text { (final } \\
\text { concn.) }\end{array}$ & $\underset{(\mu \mathrm{l})}{\mathrm{CO}_{2} \text { evolved }}$ & $\begin{array}{c}\text { Inhibition } \\
(\%)\end{array}$ & $\begin{array}{l}\text { Increase in } \\
\text { inorg. } P \\
(\gamma)\end{array}$ \\
\hline 1 & 130 & $\begin{array}{l}\text { Tartarate } \\
\text { Tartarate } \\
\text { Tartarate }\end{array}$ & $\begin{array}{l}\mathrm{M} / \overline{150} \\
\mathrm{M} / 300\end{array}$ & $\begin{array}{l}65.5 \\
13.8 \\
29.5\end{array}$ & $\begin{array}{l}\overline{79.0} \\
54.9\end{array}$ & $\begin{array}{l}+1.8 \\
+0.5 \\
+0.3\end{array}$ \\
\hline 2 & 60 & $\begin{array}{l}\text { Tartarate } \\
\text { Tartarate }\end{array}$ & $\mathrm{M} \overline{\mathrm{6}} 00$ & $\begin{array}{l}43.9 \\
43.1\end{array}$ & $\overrightarrow{2.0}$ & $\begin{array}{l}-* \\
+1.5\end{array}$ \\
\hline 3 & 175 & $\begin{array}{l}\text { Phosphoglycerate } \\
\text { Phosphoglycerate } \\
\text { Phosphoglycerate }\end{array}$ & $\begin{array}{c}\vec{M} / 300 \\
\mathrm{M} / 600\end{array}$ & $\begin{array}{l}20.3 \\
0 \\
0\end{array}$ & $\begin{array}{c}\overline{-} \\
100.0 \\
100.0\end{array}$ & $\begin{array}{l}+23.5 \\
+0.5 \\
+1.5\end{array}$ \\
\hline
\end{tabular}

Experiments were carried out in Warburg's vessels. Each flask contained $5.8 \mathrm{mg}$ (dry wt.) of cells, $20 \mu \mathrm{M}$ of tartarate or $8 \mu \mathrm{M}$ of $\mathrm{D}-(-)$-phosphoglycerate as substrate, $\mathrm{NaF}$ as shown in the table, $0.5 \mathrm{ml}$. of $\mathrm{M} / 150$ phosphate buffer $(\mathrm{pH}=5.4)$ and water to make the final volume $2.0 \mathrm{ml}$. Temp.; $30^{\circ} \mathrm{C}$. Gas phase; $\mathrm{N}_{2}$.

* Not determined by accident. 
d) Inhibition experiments with malonate, $\alpha, \alpha^{\prime}$-dipyridyl and $K C N$.

From the results of the previous experiments the possibility of the occurence of Scheme I was excluded; consequently, the validity of Scheme II was examined next. Scheme II assumes oxalacetate as the first intermediate. If this is so, then the decomposition of tartarate should also be inhibited, when the decarboxylation of the oxalacetate is inhibited by suitable inhibitors. Although the specific inhibitor of the decarboxylation of oxalacetate was not known, malonic acid, in its higher concentration, is reported to inhibit the oxalacetate decarboxylase in addition to the succinic acid dehydrogenase ${ }^{(10,25)}$, and $\alpha, \alpha^{\prime}$-dipyridyl is reported to inhibit the decarboxylation of oxalacetate by Bact. succinicum ${ }^{(22)}$. Therefore the effects of these substances on the anaerobic decomposition of tartarate and of oxalacetate were investigated (Table 7 ).

Table 7. The effects of various inhibitors on the anaerobic decomposition of tartarate and oxalacetate.

\begin{tabular}{|c|c|c|c|c|c|}
\hline $\begin{array}{c}\text { Exptl. } \\
\text { No. }\end{array}$ & $\begin{array}{l}\text { Time of } \\
\text { incubation } \\
\text { (min.) }\end{array}$ & $\begin{array}{c}\text { Substrate } \\
\text { (final concn.) }\end{array}$ & $\begin{array}{c}\text { Inhibitor } \\
\text { (final conen.) }\end{array}$ & $\begin{array}{l}\mathrm{CO}_{2} \text { evolved } \\
(\mu \mathrm{l})\end{array}$ & $\begin{array}{c}\text { Inhibition } \\
(\%)\end{array}$ \\
\hline 1 & 40 & $\begin{array}{l}\text { Tartarate } \\
(\mathrm{M} / 100)\end{array}$ & $\begin{array}{l}\text { Malonate }(\mathrm{M} / 200) \\
\text { Malonate }(\mathrm{M} / 40)\end{array}$ & $\begin{array}{l}56.7 \\
46.3 \\
31.0\end{array}$ & $\begin{array}{l}\overline{18.4} \\
45.4\end{array}$ \\
\hline 2 & 30 & $\begin{array}{l}\text { Oxalacetate } \\
(\mathrm{M} / 210)\end{array}$ & Malonate $(\mathrm{M} / 42)$ & $\begin{array}{l}52.3 \\
25.3\end{array}$ & $\overline{51.6}$ \\
\hline 3 & 40 & $\begin{array}{c}\text { Tartarate } \\
(\mathrm{M} / 85)\end{array}$ & $\begin{array}{l}\text { Dipyridyl }(\mathrm{M} / 1700) \\
\text { Dipyridyl }(\mathrm{M} / 340)\end{array}$ & $\begin{array}{l}55.3 \\
42.7 \\
30.0\end{array}$ & $\begin{array}{l}-\overline{22.8} \\
45.7\end{array}$ \\
\hline 4 & 24 & $\begin{array}{l}\text { Oxalacetate } \\
(\mathrm{M} / 240)\end{array}$ & Dipyridyl (M/330) & $\begin{array}{l}33.5 \\
12.6\end{array}$ & $\overline{62.3}$ \\
\hline 5 & 30 & $\begin{array}{l}\text { Tartarate } \\
(\mathrm{M} / 100)\end{array}$ & $\begin{array}{l}\operatorname{KCN}(M / 400) \\
\operatorname{KCN}(M / 10)\end{array}$ & $\begin{array}{c}97.8 \\
34.8 \\
0\end{array}$ & $\begin{array}{r}64.4 \\
100.0\end{array}$ \\
\hline 6 & 30 & $\begin{array}{l}\text { Tartarate } \\
(\mathrm{M} / 450)\end{array}$ & $\overline{\mathrm{KCN}}(\mathrm{M} / 1800)$ & $\begin{array}{l}43.3 \\
45.8\end{array}$ & $\overline{0}$ \\
\hline
\end{tabular}

Experiment 2 and 4 were performed with dried preparations. Boiled preparations were used to correct the non-enzymatic decomposition of oxalacetate. Other experiments were performed with resting cell suspensions.

As shown in Table 7 both reactions were inhibited by dipyridyl $(M / 340)$ and malonate $(\mathrm{M} / 40)$ almost to the same degree. This result supported the occurence of Scheme II.

Table 7 also shows that the anaerobic decomposition of tartarate was inhibited by the higher concentration of $\mathrm{KCN}$, a known keton reagent, but not by its lower concentration.

e) Anaerobic docomposition of $D-(-)$-malate and pyruvate.

The anaerobic decomposition of $\mathrm{D}-(-)$-malate and pyruvate, the inter- 
mediates presumed in Scheme II, were investigated. If the anaerobic decomposition of malate is performed according to Scheme II as in the case of tartarate, dismutation to succinate, acetate, and $\mathrm{CO}_{2}$ according to equation (9) is to be expected.

$$
3 \underset{\mathrm{CH}(\mathrm{OH})-\mathrm{COOH}}{\mathrm{CH}_{2}-\mathrm{COOH}}=2 \underset{\mathrm{CH}_{2}-\mathrm{COOH}}{\mathrm{CH}_{2}-\mathrm{COOH}}+\mathrm{CH}_{3} \mathrm{COOH}+2 \mathrm{CO}_{2}+\mathrm{H}_{2} \mathrm{O} \ldots \ldots \text { (9) }
$$

The experimental analysis confirmed this supposition (Table 8).

Table 8. Anaerobic decomposition of D-(-)-malate.

\begin{tabular}{l|c|c|c|c}
\hline & \multicolumn{3}{|c|}{ Observed value } & $\begin{array}{c}\text { Theoretical value } \\
\text { molar ratio accord- } \\
\text { ing to eq. (9) }\end{array}$ \\
\cline { 2 - 5 } D-(-)-Malic acid added & $\mathrm{mg}$ & $\mu \mathrm{M}$ & Molar ratio & \\
$\mathrm{D}-(-)$-Malic acid remained & 42.9 & 320 & & \\
$\mathrm{D}-(-)$-Malic acid consumed & 42.9 & 320 & 3.00 & 3 \\
$\mathrm{CO}_{2}$ formed & 8.95 & 203.5 & 1.90 & 2 \\
Succinic acid formed & 20.1 & 170.2 & 1.59 & 2 \\
Acetic acid formed & 3.88 & 64.6 & 0.60 & 1 \\
\hline
\end{tabular}

Experiments were carried out in a large Thunberg tube. Cells $40 \mathrm{mg}$ dry weight, M/15 phosphate buffer $(\mathrm{pH}=5.4) 12 \mathrm{ml}$. Na-DL-malate $640 \mu \mathrm{M}$, and water. Total volume; $40 \mathrm{ml}$. Air was removed by evacuation. Temp.; $30^{\circ} \mathrm{C}$. Time; $4 \mathrm{hrs}$.

Table 9. Anaerobic decomposition of pyruvate.

\begin{tabular}{|c|c|c|c|c|c|}
\hline \multirow{2}{*}{$\begin{array}{c}\text { Exptl. } \\
\text { No. }\end{array}$} & & \multicolumn{3}{|c|}{ Observed value } & \multirow{2}{*}{$\begin{array}{l}\text { Theoretical value } \\
\text { molar ratio accord- } \\
\text { ing to eq. ( } 7)\end{array}$} \\
\hline & & $\mathrm{mg}$ & $\mu \mathrm{M}$ & $\begin{array}{c}\text { Molar } \\
\text { ratio }\end{array}$ & \\
\hline \multirow[t]{8}{*}{$1 *$} & Pyruvic acid added & 25.4 & 288 & & \\
\hline & Pyruvic acid remained & 0 & 0 & & \\
\hline & Pyruvic acid consumed & 25.4 & 288 & 1.00 & 1 \\
\hline & Acetic acid formed & 15.6 & 260 & 0.90 & 1 \\
\hline & Formic acid formed & 2.1 & 46 & 0.16 & \\
\hline & Succinic acid formed & 0.50 & 4.2 & & \\
\hline & Acetoin formed & 0.54 & 8.1 & & \\
\hline & Diacetyl formed & 0 & 0 & & \\
\hline \multirow[t]{3}{*}{$2 * *$} & Pyruvic acid consumed & & 3.6 & 1.00 & 1 \\
\hline & $\mathrm{CO}_{2}$ formed & & 3.7 & 1.03 & 1 \\
\hline & $\mathrm{H}_{2}$ formed & & 2.8 & 0.78 & 1 \\
\hline
\end{tabular}

* Experimental conditions were the same as in Table 8 except that $288 \mu \mathrm{M}$ of pyruvate was added instead of malate, and the time of incubation was $130 \mathrm{~min}$.

** Determined manometrically in a separate experiments under the similar conditions. 
It was already shown (Table 5) that net fixation of $\mathrm{CO}_{2}$, as claimed in Scheme I, was not observed when phosphoglycerate was the substrate. In the next experiment further examination of the possibility of net $\mathrm{CO}_{2}$ fixation reaction, $\mathrm{C}_{3}+\mathrm{C}_{1} \rightarrow \mathrm{C}_{4}$, was undertaken quantitatively using pyruvate as the substrate (Table 9). Table 9 shows that pyruvate is metabolized according to equation (10) and the formation of $\mathrm{C}_{4}$ compounds such as succinate, acetoin, and diacetyl, was negligibly small.

$$
\mathrm{CH}_{3} \mathrm{COCOOH}+\mathrm{H}_{2} \mathrm{O}=\mathrm{CH}_{3} \mathrm{COOH}+\mathrm{CO}_{2}+\mathrm{H}_{2}
$$

In this case too then, the net $\mathrm{CO}_{2}$ fixation reaction seems not to occur.

Part 2. Aerobic decomposition of $\mathrm{L}(+)$-tartarate.

\section{Oxidation of tartarate by resting cells.}

The resting cell suspension of $P$ s. incognita strain $3 L$ which was grown in a medium containing tartarate rapidly oxidizes tartarate without an appreciable lag (Non-adapted cells oxidize tartarate only after a 50 to 80 min. lag period.). The amounts of $\mathrm{O}_{2}$ uptake and $\mathrm{CO}_{2}$ output were measured manometrically. About 1.3 molecule of $\mathrm{O}_{2}$ uptake and 2.6 molecule $\mathrm{CO}_{2}$ output were observed per molecule of tartarate added. The observed $\mathrm{RQ}$ is about 2.0 at the end of the reaction.

Fig. 1 shows one example of such experiments.

Since these observed values are far below those required for the complete oxidation of tartarate (2.5 molecule $\mathrm{O}_{2}$ uptake and 4 molecule $\mathrm{CO}_{2}$ output per molecule of tartarate; $R Q=1.6$ ), the search for the oxidation products was attempted using the aerobically grown resting cell suspension. The composition of the reaction mixture was as follows: cell suspension (2.34 g (dry wt.) of cells in $0.2 \% \mathrm{KCl}) 384 \mathrm{ml}$., M 15 phosphate buffer $(\mathrm{pH}=5.4) 576 \mathrm{ml}$., M/10 $\mathrm{Na}$ tartarate solution (containing $2.88 \mathrm{~g}$ free tartaric acid), total volume $1152 \mathrm{ml}$. This reaction mixture was divided into 20 flasks and was shaken at $25^{\circ} \mathrm{C}$. After 250 min., when oxidation had ceased as judged manometrically in the parallel experiments, the reaction was arrested by acidifying the medium to $\mathrm{pH} 2$ with $10 \mathrm{~N}$

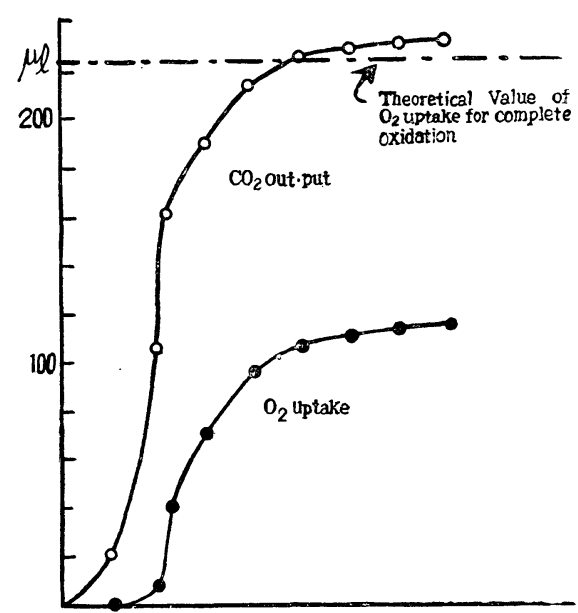

Fig. 1. The oxidation of tartarate by $P$ s. incognita strain $3 L$.

Composition of the reaction mixture: cell $5.1 \mathrm{mg}$ dry wt. Na tartrate $4 \mu \mathrm{M}, \mathrm{M} / 15$ phosphate buffer $(\mathrm{pH}=5.4) 1.0 \mathrm{ml}$., total volume $1.7 \mathrm{ml}$. Temp., $30^{\circ} \mathrm{C}$, Gas phase, air. 
$\mathrm{H}_{2} \mathrm{SO}_{4}$ and the reaction medium was analyzed by methods similar to those described in experiment 1 of part 1 . Very small amounts of pyruvate, unknown keto acid (possibly $\alpha$-ketoglutarate judging from the Rf value of paperchromatography), and residual tartarate were detected but no other products were found.

\section{The effect of 2,4-dinitrophenol on the oxidiation of tartarate.}

As described in the previous section no accumulation of products was observed when tartarate was oxidized and yet the amount of $\mathrm{O}_{2}$ uptake or $\mathrm{CO}_{2}$ out put never reached the theoretical value of the complete oxidation. Therefore it is thought that a part of the tartarate may be assimilated and the other part may be completely oxidized. In order to test this assumption, the oxidation of tartarate was performed in the presence of 2,4-dinitrophenol, a known inhibitor of oxidative assimilation.

As shown in Table 10, the observed values for $\mathrm{O}_{2}$ uptake and $\mathrm{CO}_{2}$ output in the presence of $\mathrm{M} / 20,000$ 2,4-dinitrophenol were close to the theoretical value for the complete oxidation of tartarate. Therefore, it seems likely that aerobically a part of tartarate is assimilated, while the other part is completely oxidized, and this oxidative assimilation is inhibited by 2,4 dinitrophenol.

Table 10. The oxidation of tartarate in the presence of 2,4-dinitrophenol.

\begin{tabular}{l|c|c|c}
\hline & \multicolumn{2}{|c|}{ Observed value } & \multicolumn{2}{c}{$\begin{array}{c}\text { Theoretical value for } \\
\text { complete oxidation } \\
\text { (Molar ratio) }\end{array}$} \\
\hline L-(+)-Tartarate added & $\mu \mathrm{M}$ & Molar ratio & 1.00 \\
$\mathrm{O}_{2}$ taken up & 4.00 & 1.00 & 2.50 \\
$\mathrm{CO}_{2}$ evolved & 8.82 & 2.21 & 4.00 \\
$\mathrm{RQ}$ & 13.5 & 3.38 & 1.60 \\
\hline
\end{tabular}

Gas volume changes were measured in the Warburg's respirometer. Composition of the reaction mixture; Na-L- $(+)$-tartarate $\mathrm{M} / 500$, phosphate buffer $(\mathrm{pH}=5.4) \mathrm{M} / 30,2$,4-dinitrophenol $5 \times 10^{-5} \mathrm{M}$, cells $3.2 \mathrm{mg}$ dry wt., total $2.0 \mathrm{ml}$. Temp. $30^{\circ} \mathrm{C}$. Gas phase, air. Time $93 \mathrm{~min}$.

In the course of these experiments it was observed that 2,4-dinitrophenol $\left(5 \times 10^{-5} \mathrm{M}\right)$ inhibited the early stage of the oxidation of tartarate but after 15 to $25 \mathrm{~min}$. the oxidation proceeded at about the normal rate and eventually the amount of $\mathrm{O}_{2}$ taken up or $\mathrm{CO}_{2}$ produced exceeded that of the control reaction (Fig. 2).

Apparently 2,4-dinitrophenol prolonged the lag period which was observed for a short time in the normal oxidation by the adapted cell. Therefore it may be that the oxidation of tartarate requires activation by some sort of mechanism using phosphate bond energy and this step is inhibited by the 2,4-dinitrophenol. 
3. The oxidation of various organic acids by the tartarate adapted and nonadapted cells.

Cells were grown in the absence of tartarate, harvested, and washed. Tartarate adapted and non-adapted resting cells were then prepared and examined as to their ability to oxidize various organic acids (Fig. 3 and 4).

No marked change following the adaptation to tartarate was observed except that the ability to oxidize acetate was depressed as a result of the adaptation to tartarate (Fig. 3; $\mathrm{Qo}_{2}$ for acetate is 17.1 for non-adapted cell and 9.5 for adapted cell). D-(-)-phosphoglycerate and DL-glycerate were oxidized slowly both by the adapted and non-adapted

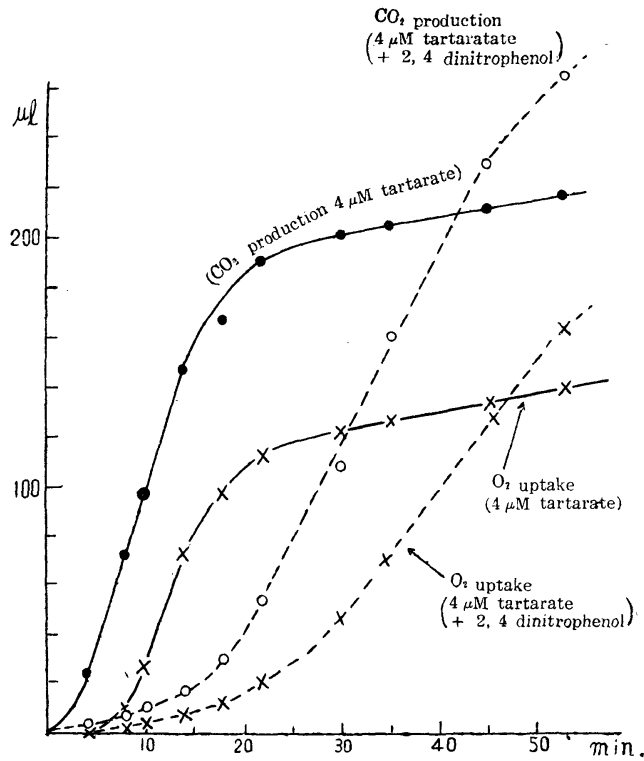

Fig. 2. The effect of 2,4-dinitrophenol on the oxidation of tartarate.

The composition of the reaction mixture was the same as that in Table 10 except that the cells used were $3.6 \mathrm{mg}$ dry wt. per cup.

cells and no marked difference between these two cases was observed (Fig. 4).

4. The oxidation of various organic acids by the resting cell grown in bouillon-tartarate medium.

The oxidation of various organic acids which might be the possible intermediates of the metabolism of tartarate were investigated using the cells grown in the usual bouillon-tartarate medium. Glycolic and fumarylglycidic acids were not oxidized. Dioxymaleic, DL-glyceric and DL-phosphoglyceric acids were oxidized very slowly. D- $(-)$ Phosphoglyceric acid was oxidized slowly $\left(\mathrm{Qo}_{2}=2-10\right.$ while $\mathrm{Qo}_{2}$ for tartarate $\left.=70-220\right)$. On the other hand oxalacetic and pyruvic acids were oxidized at nearly same rate as tartarate without any appreciable lag period (See also Fig. 3 (a)).

The lag period of $\mathrm{O}_{2}$ uptake in the oxidation of tartarate was more marked when the concentration of tartarate was decreased, while the evolution of $\mathrm{CO}_{2}$ from tartarate was observed to proceed without any appreciable lag period (Fig. 1 and 2). Consequently the RQ at the early stage is far greater than 2 and, as the reaction proceeds, decreases gradually to 2 , the value at the end of the reaction. In the experiment shown in Fig. 1, $\mathrm{CO}_{2}$ output from $4 \mu \mathrm{M}$ of tartarate after $10 \mathrm{~min}$. was $107.4 \mu \mathrm{l}$ or $4.7 \mu \mathrm{M}$ while $\mathrm{O}_{2}$ uptake was only $11.2 \mu \mathrm{l}$ or $0.5 \mu \mathrm{M}$. Therefore, 1 molecule 
(a) By adapted cell

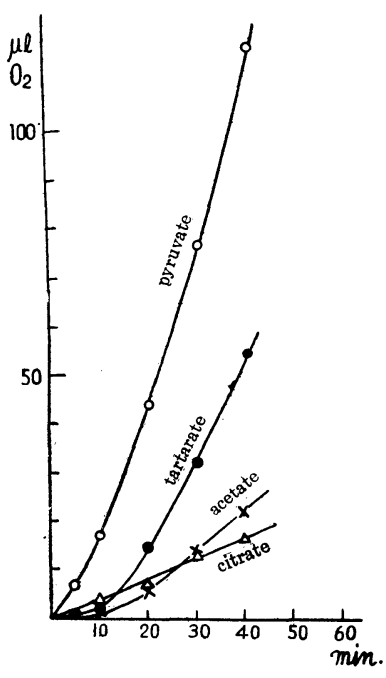

(b) By non-adapted cell

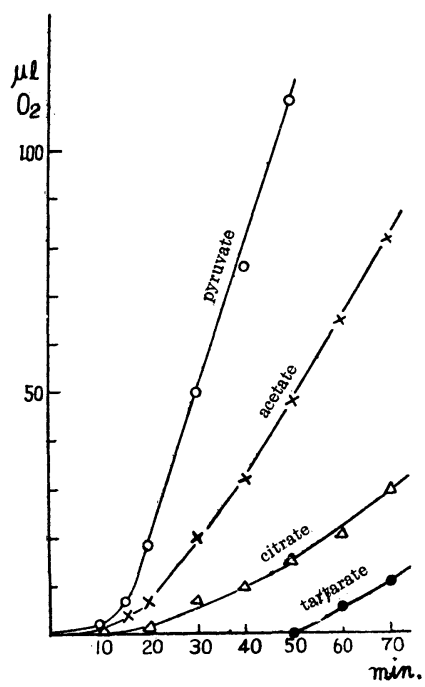

Fig. 3. The oxidation of various substrates by Ps. incognita strain $3 L$.

Cells were grown in a glucose medium (glucose $2 \%,\left(\mathrm{NH}_{4}\right)_{2} \mathrm{SO}_{4} 0.2 \%$, peptone $0.1 \%, \mathrm{~K}_{2} \mathrm{HPO}_{4} 0.1 \% \mathrm{pH}=6.8$ ) at $30^{\circ} \mathrm{C}$ for $22 \mathrm{hrs}$., harvested, washed and the resting cell suspension was divided into 2 parts and shaken in $\mathrm{M} / 53$ phosphate buffer $(\mathrm{pH}=7.0)$ with and without tartarate $(\mathrm{M} / 60)$. The two resulting cell suspensions, tartarate adapted and non-adapted cells, were harvested, washed and used for the experiment. Composition of the reaction mixture: cells 5.3 $\mathrm{mg}$ in (a) and $5.6 \mathrm{mg}$ in (b), phosphate $\mathrm{M} / 25(\mathrm{pH}=7.0)$, substrate as shown in the figure $\mathrm{M} / 85$, total volume $1.7 \mathrm{ml}$. Temp., $30^{\circ} \mathrm{C}$. Gas phase, air.

of net $\mathrm{CO}_{2}$ production from 1 molecule of tartarate was observed for this period.

These observations trongly indicate that the first step of the aerobic decomposition of tartarate is its decarboxylation via oxalacetate to pyruvate (eq. (11)) and not its oxidation to dioxymaleate before decarboxylation (eq. (12)).
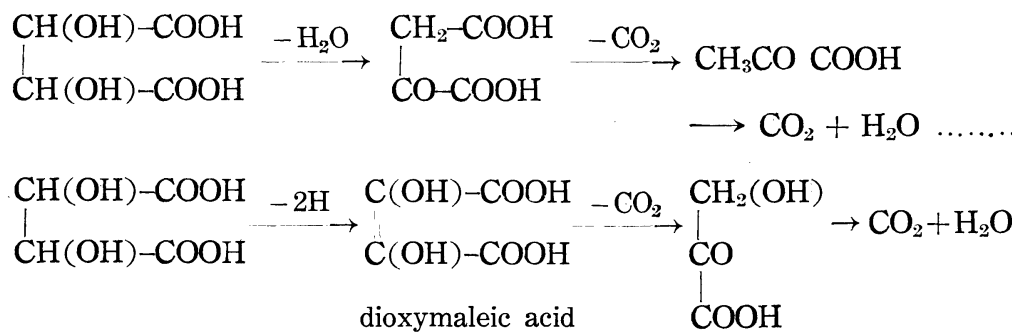

hydroxypyruvic acid 

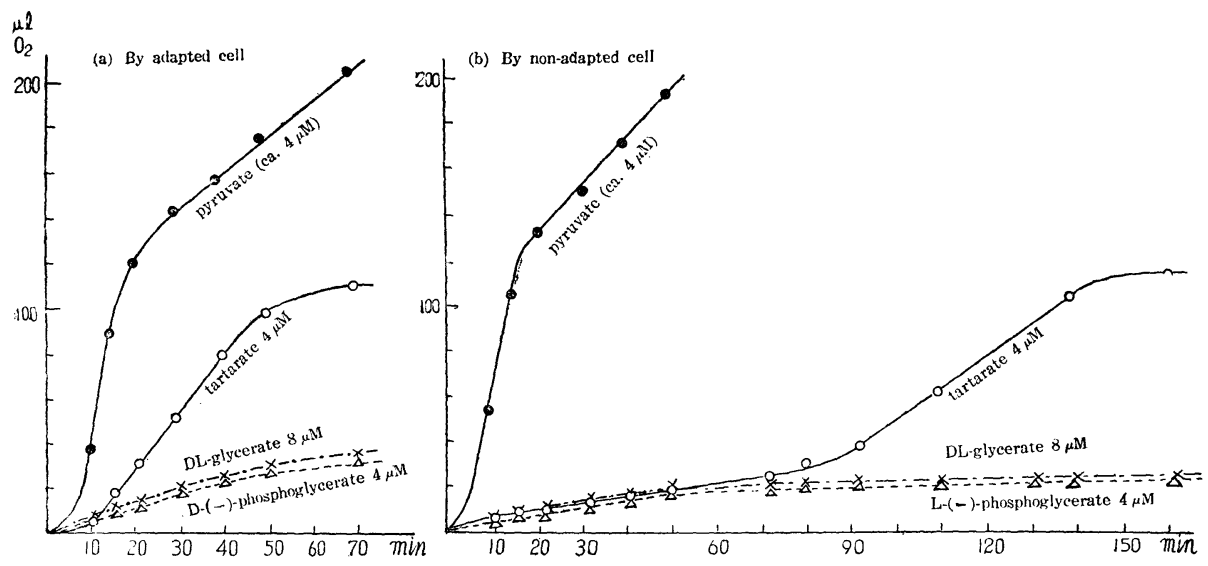

Fig. 4. The oxidation of various substrates by Ps. incognita strain $3 L$.

Cells were grown in an acetate medium $\left(\mathrm{Na}\right.$ acetate $\cdot 3 \mathrm{H}_{2} \mathrm{O} 1.2 \%,\left(\mathrm{NH}_{4}\right)_{2} \mathrm{SO}_{4}$ $0.2 \%, \mathrm{~K}_{2} \mathrm{HPO}_{4} 0.1 \%$, pepton $0.1 \%, \mathrm{pH}=6.4$ ) at $25^{\circ} \mathrm{C}$ for $46 \mathrm{hrs}$. Tartarate adapted and non-adapted cells were prepared by a method similar to the one described in Fig. 4. Composition of the reaction mixture: cells $6.7 \mathrm{mg}$, phosphate $\mathrm{M} / 31.5(\mathrm{pH}=5.4)$, substrate as indicated in the figure. Total volume, $2.1 \mathrm{ml}$. Temp., $30^{\circ} \mathrm{C}$. Gas phase, air.

\section{Search for the primary decarboxylation product.}

When tartarate was decomposed aerobically $\mathrm{CO}_{2}$ production was observed immediately while $\mathrm{O}_{2}$ uptake started only after the lag period. Consequently it was supposed that the primary decarboxylation products might accumulate in the medium at the early stage. Therefore the search for this compound was attempted. The reaction mixture (M/36 phosphate buffer containing $4.8 \mathrm{~g}$ of tartaric acid and $1.52 \mathrm{~g}$ dry wt. of cell, $\mathrm{pH}=5.4$, total volume $960 \mathrm{ml}$.) was shaken at $30^{\circ} \mathrm{C}$ for $10 \mathrm{~min}$.

The reaction was then immediately arrested by adding $\mathrm{H}_{2} \mathrm{SO}_{4}$ and the medium was analyzed. Very small amounts of pyruvate and $\alpha$-ketoglutarate were detected by paperchromatography ( $R f=0.65$ and 0.11 respectively). Control experiments did not show these keto acids. But their amounts were too small to account for the observed gas changes. Besides these keto acids and residual tartaric acid, no accumulation of organic acids was observed in the medium.

Therefore this attempt was fruitless.

6. The effect of arsenite and monojodacetate on the aerobic oxidation of tartarate and pyruvate.

If the first step of the aerobic decomposition of tartarate is its decarboxylation to pyruvate prior to its dehydrogenation, the $\mathrm{O}_{2}$ uptake due to tartarate should be inhibited by the inhibitors which inhibit the oxidation of pyruvate. Morover, if this inhibitor is suitably selected the reaction from tartarate to pyruvate could be demonstrated without any confusion 
by the oxygen uptake of the subsequent reaction.

Arsenite and monojodacetate were tested from this point of view (Table 11).

Table 11. The effect of arsenite and monojodacetate on the aerobic decomposition of tartarate and pyruvate.

\begin{tabular}{|c|c|c|c|c|c|c|c|c|}
\hline \multirow{2}{*}{$\begin{array}{c}\text { Exptl. } \\
\text { No. }\end{array}$} & \multirow{2}{*}{$\begin{array}{c}\text { Time of } \\
\text { incuba- } \\
\text { tion } \\
\text { (min.) }\end{array}$} & \multirow{2}{*}{$\begin{array}{c}\text { Substrate } \\
\text { (final } \\
\text { concn.) }\end{array}$} & \multirow[b]{2}{*}{$\begin{array}{l}\text { Inhibitor } \\
\text { (final concn.) }\end{array}$} & \multicolumn{2}{|c|}{$\mathrm{O}_{2}$ uptake } & \multicolumn{2}{|c|}{$\mathrm{CO}_{2}$ out put } & \multirow[b]{2}{*}{$\mathrm{RQ}$} \\
\hline & & & & $\begin{array}{c}\text { Obser- } \\
\text { ved } \\
\mu l\end{array}$ & $\begin{array}{c}\text { Inhibi- } \\
\text { tion } \\
\% \\
\end{array}$ & $\begin{array}{c}\text { Obser- } \\
\text { ved } \\
\mu 1\end{array}$ & $\begin{array}{c}\text { Inhibi- } \\
\text { tion } \\
\%\end{array}$ & \\
\hline 1 & 45 & $\begin{array}{c}\text { Tartarate } \\
(\mathbf{M} / 390)\end{array}$ & $\mathrm{As}_{2} \mathrm{O}_{3} \overline{(\mathrm{M} / 1200)}$ & $\begin{array}{l}91.0 \\
33.8\end{array}$ & $\overrightarrow{63}$ & $\begin{array}{l}216.0 \\
109.1\end{array}$ & $\overline{49}$ & $\begin{array}{l}2.37 \\
3.23\end{array}$ \\
\hline 2 & 21 & $\begin{array}{c}\text { Pyruvate } \\
(\mathrm{M} / 780)\end{array}$ & $\mathrm{As}_{2} \mathrm{O}_{3} \overline{(\mathrm{M} / 1200)}$ & $\begin{array}{l}54.0 \\
14.0\end{array}$ & $\overrightarrow{74}$ & * & & \\
\hline 3 & 30 & $\begin{array}{c}\text { Tartarate } \\
(\mathrm{M} / 525)\end{array}$ & $\mathrm{CH}_{2} \mathrm{ICOONa}(\mathrm{M} / 525)$ & $\begin{array}{r}185.9 \\
6.3\end{array}$ & $\overrightarrow{97}$ & 41.3 & - & $6 . \overrightarrow{1}$ \\
\hline 4 & 20 & $\begin{array}{c}\text { Pyruvate } \\
(\mathrm{M} / 525)\end{array}$ & $\mathrm{CH}_{2} \mathrm{ICOONa}(\mathrm{M} / 525)$ & $\begin{array}{r}106.9 \\
14.1\end{array}$ & $\overline{86}$ & $\begin{array}{l}* \\
*\end{array}$ & & \\
\hline
\end{tabular}

Cells used: $8.5 \mathrm{mg}$ dried cells in Expt. 1 and 2. $5.0 \mathrm{mg}$ intact cells in Expt. 3 and 4 .

* Not determined.

As shown in Table 11 both arsenite and monojodacetate which inhibited the oxidation of pyruvate inhibited the oxidation of tartarate almost to the same degree. Particulary interesting are the results obtained with monojodacetate. This compound inhibited the $\mathrm{O}_{2}$ uptake due to tartarate almost completely while $\mathrm{CO}_{z}$ production still proceeded, though at very slow rate. Consequently, the $R Q$ value is, after 30 min., still 6.1 in the presence of monojodacetate instead of 2.0 to 2.4 as in the normal case. These results support the above conclusion that the first step of the aerobic decomposition of tartarate is its decarboxylation to the pyruvate stage and not its dehydrogenation to the dioxymaleic acid stage.

Since DL-glycerate and phosphoglycerate are oxidized only at very slow rates and this rate is not increased by the adaptation to tartarate (Fig. 4) these $\mathrm{C}_{3}$ conpounds are unlikely to be the intermediates in the decomposition of tartarate. Furthermore, in the anaerobic decomposition of tartarate, tartarate is decomposed according to Scheme II rather than Scheme I as already described. Therefore, aerobically too, tartarate may first be converted to pyruvate via oxalacetate and then oxidized by the usual TCA-cycle or a similar cycle (The appearence of $\alpha$-ketoglutarate in addition to pyruvate at the early stage of tartarate oxidation suggests the occurrence of the TCA-cycle).

Part 3. Attempts to extract the enzyme system in a cell free state.

Thus far the study was performed with the intact cells or the dried 
cell preparations. In order to prove more conclusively the first step of the decomposition of tartarate attempts were made to extract the enzyme system in a cell free state by means of various methods.

The dried cell preparations were ground in a ball mill and the freshly harvested cells were ground with alumina or sand. But in the clear supernatant solution obtained after high speed centrifugation no activity was ever found. On the other hand, in the particulate fraction the enzymatic activity was found occasionaly.

From the results of the 2,4 dinitrophenol experiments already described it was thought that the lack of the enzymatic activity in the supernatant fraction toward tartarate might be due to the lack of the activating mechanism of the phosphate bond energy. This possibility was examined. First the supernatant fraction was coupled with the plant mitochondria obtained from the mug bean according to the method of Maruo et al. (12) but without success. The addition of ATP to the supernatant also did not show any marked effect. However, when monophosphotartarate prepared according to the method of Neuberg et al.(15) was tested as the substrate, this compound was decomposed anaerobically by the enzyme preparation which did not show any activity upon tartarate and 1 molecule of $\mathrm{CO}_{2}$ was evolved per molecule of phosphotartarate metabolized (as judged by the increase of inorganic phosphate) (Table 12). This result does not necessarily prove phosphotartarate to be the intermediate in the anaerobic decomposition of tartarate, but it strongly suggests the existence of some

Table 12. The anaerobic decomposition of phosphotartarate by the enzyme preparation.

\begin{tabular}{l|c|c|c|c}
\hline \multirow{2}{*}{ Substrate added } & \multicolumn{2}{|c|}{$\mathrm{CO}_{2}$ evolved } & \multicolumn{2}{|c}{ Inorganic P. increased } \\
\cline { 2 - 4 } & $\mu \mathrm{l}$ & $\mu \mathrm{M}$ & $\gamma$ & $\mu \mathrm{M}$ \\
\hline $\begin{array}{c}\text { Phosphotartarate }(4 \mu \mathrm{M}) \\
\text { Tartarate }(4 \mu \mathrm{M})\end{array}$ & 26.1 & 1.17 & 37.7 & 1.22 \\
$\begin{array}{c}\text { Phosphotartarate }(4 \mu \mathrm{M}) \\
\text { +tartarate }(4 \mu \mathrm{M})\end{array}$ & 4.8 & 0.21 & 3.7 & 0.12 \\
\hline
\end{tabular}

Freshly harvested cells were chilled and ground with alumina and then extracted with $0.2 \% \mathrm{KCl}$ solution. Alumina was removed by low speed centrifugation for $5 \mathrm{~min}$. Then the cell debris was removed by high speed centrifugation (about 8,000 to 10,000 r.p.m.) for $10 \mathrm{~min}$. Resultant cloudy, reddish yellow solution which contained some particulate matter was used as the enzyme solution. The reaction was carried out in Warburg's respirometer. The composition of the reaction mixture: enzyme solution $0.5 \mathrm{ml}$., M/150 phosphate buffer $(\mathrm{pH}=5.4) 0.4 \mathrm{ml}$., tartarate or phosphotartarate as indicated in the table. Total volume, $1.3 \mathrm{ml}$. Gas phase, $\mathrm{N}_{2}$. Temp., $30^{\circ} \mathrm{C}$. After $70 \mathrm{~min}$. the reaction was stopped by adding $0.2 \mathrm{ml}$. of $10 \mathrm{~N} \mathrm{H}_{2} \mathrm{SO}_{4}$. The precipitated protein was removed and inorg. $\mathrm{P}$ was determined in the supernatant solution. 
mechanims which activates tartarate.

Phosphotartarate was also oxidized slowly by intact cells and by dried cell preparations $\mathrm{Qo}_{2}=2.7$ with the intact cells and 8.2 with the dried cell preparations).

Part 4. Possible mechanism of the formation of tartarate in the plant.

From the experiments described in this paper it was concluded that tartarate is metabolized via oxalacetate under aerobic as weil as anaerobic conditions. Oxalacetate is situated at the key position of the tricarboxylic acid cycle or $\mathrm{C}_{4}$-dicarboxylic acid cycle and at this point the metabolism of tartarate seems to be linkded with the main path of cellular metabolism. Since in the isotopic experiment shown in Table 2 and 3 , the incorporation of $\mathrm{C}^{14}$ into carboxyl carbons of residual tartarate was observed, the reaction from tartarate to oxalacetate seems to be reversible and the formation of tartarate by this reaction may also be possible. In the plant tartarate is widely distributed, particularly in the leaf, and there the interconversion between this acid and other $\mathrm{C}_{4}$ or $\mathrm{C}_{6}$ acids is occasionaly observed. Though no direct experimental observations on the metabolism of tartarate in the plant have been made, it may be supposed from the results obtained in this paper that in plants too, tartarate may be formed or metabolized via oxalacetate and thus playing some role together with other stored organic acids. But the final conclusion on this point will require the direct demonstration of this reaction by an enzyme preparation obtained from plant tissue.

\section{SUMMARY}

Using Pseudomonas incognita strain $3 L$ aerobic and anaerobic decomposition of $\mathrm{L}-(+)$-tartarate was investigated.

Succinic and acetic acids were isolated and identified as the anaerobic decomposition products of tartarate by resting cells. Furthermore, from the balance studies it was clearly established that anaerobic decomposition of tartarate is performed according to eq. (3).

In order to clarify the mechanism of this reaction, anaerobic decomposition of tartarate by resting cells was conducted in the presence of radioactive bicarbonate and the incorporation of $\mathrm{C}^{14} \mathrm{O}_{2}$ into various compounds was examined. From the experimental results two schemes (Scheme I and II) were proposed to explain the observed incorporations of the isotope. But the following experimental results exciuded the possibility of Scheme I as the main path of the anaerobic decomposition of tartarate by this organism.

(1) $\mathrm{D}-(-)$-Phosphoglycerate was decomposed anaerobically and about 1 molecule of $\mathrm{CO}_{2}$ was evolved per molecule of phosphoglycerate consumed, while $1 / 3$ molecule of $\mathrm{CO}_{2}$ should be expected if this compound were metabolized according to Scheme I. Therefore $\mathrm{CO}_{2}$ fixation reaction according to Scheme I did not occur under these conditions. From the thermodynamic 
point of view, the $\mathrm{CO}_{2}$ fixation reaction according to Scheme I may be performed more easily when phosphoglycerate rather than tartarate is the substrate. Therefore this experimental result makes Scheme I unlikely.

(2) Similarly succinate formation by the $\mathrm{CO}_{2}$ fixation reaction was not observed in the anaerobic decomposition of pyruvate.

(3) $\mathrm{NaF}$, in the final concentration of $\mathrm{M} / 600$, completely inhibited the decomposition of phosphoglycerate, whereas the decomposition of tartarate was not inhibited in the same concentration. Therefore phoshoglycerate was excluded as the intermediate.

(4) Anaerobically, DL-glcerate was not metabolized by this organism and is not likely to be the intermediate.

On the other hand the validity of Scheme II was further supported by the observation that both oxalacetate decarboxylation and tartarate decomposition were inhibited by dipyridyl $(\mathrm{M} / 340)$ and malonate $(\mathrm{M} / 40)$ almost to the same extent (40 to $60 \%$ ). Anaerobic decomposition of malic acid was also shown to follow Scheme II. From these experimental results it was concluded that this decomposition may proceed via oxalacetate according to the Scheme II.

Aerobic decomposition of tartarate was studied. It was demonstrated that normally a part of tartarate was assimilated while the other part was completely oxidized and no appreciable accumulation of the decomposition products was observed. 2,4 Dinitrophenol inhibited this oxidative assimilation process.

In the normal oxidation of tartarate by the adapted cells a marked lag period was observed in the $\mathrm{O}_{2}$ uptake and yet $\mathrm{CO}_{2}$ production started without any appreciable lag. In some instances apparently 1 molecule of net $\mathrm{CO}_{2}$ production from 1 molecule of tartarate was observed in this early stage without any confusion by the subsequent oxygen uptake. Furthermore, in the presence of monojodacetate $\mathrm{O}_{2}$ uptake was almost completely inhibited and yet $\mathrm{CO}_{2}$ production proceeded though at a quite small rate. These observations clearly indicated that the first step of the aerobic decomposition of tartarate is its decarboxylation to the pyruvate stage (possibly via oxalacetate as shown by the other experimental results) and not its dehydrogenation to dihydroxymaleic acid. This conclusion was further supported by the fact that various inhibitors which inhibited pyruvate oxidation also inhibited the oxidation of tartarate. Since DLglycerate and phosphoglycerate were oxidized only at a very slow rate and the rates were not increased by the adaptation to tartarate, they are unlikely to be the intermediates in the aerobic decomposition, as clearly demonstrated in the anaerobic decomposition.

Monophosphotartarate was decomposed anaerobically by the enzyme preparation which did not show any activity toward tartarate. This result, together with that of the 2,4 dinitrophenol inhibition experiments shown in Fig. 2, suggested the existence of an activation mechanism of tartarate. 


\section{REFERENCES}

(1) Benson, A. A., Calvin, M., HaAs, V. A., Aronoff, S., Hall, A. G., Bassham, J. A. and Weigl, J. W., in Frank, J. and Loomis, W. E.: Photosynthesis in Plants, Iowa State College Press, (1949).

(2) Buchanan, J. G., Bassham, J. A., Benson, A. A., Bradley, D. F., Calvin, M., Daus, L. L., Goodman, M., Hayes, P. M., Lynch, V. H., Norris, L. T. and Wilson, A. T.: Phosphorous Metabolism, II, 440 (1952).

(3) Calvin, M. and Benson, A. A.: The path of carbon in photosynthesis, Science, 107, 476 (1948).

(4) Calvin, M., Heidelberger, C., Reid, J. C., Tolbert, B. M. and Yankwich, P. E.: Isotopic Carbon, John Willey and Sons, Inc., New York (1949).

(5) Cavallini, D., Frontali, N. and Toshi, G.: Determination of keto acids by partition chromatography on filter paper, Nature, 163, 568 (1949).

(6) Fiske, C. H. and Subbarow, Y.: The colorimetric determination of phosphorus, J. Biol. Chem., 66, 375 (1925).

(7) Foster, J. W. and CArson. S. F.: Metabolic exchange of $\mathrm{CO}_{2}$ with carboxyls and oxidative synthesis of $\mathrm{C}_{4}$ dicarboxylic acids, Proc. Nat. Acad. Sci., 36. 219 (1950).

(8) Friedeman, T. E., Contonio, M. and Schaffer, P. A.: The determination of lactic acid, J. Biol. Chem., 73, 335 (1927).

(9) Kiessling, W.: Die Synthese der isomeren Glycerin säre phosphor säure, Ber., 68, 243 (1935).

(10) LiebecQ, C. and Peters, R. A.: Toxicity of fluoroacetate and the tricarboxylic acid cycle, Biochim. et Biophys. Acta, 3, 215 (1949).

(11) LugG, J. W. H. and Overell, B. T.: Partition chromatography of organic acids on a paper sheet support, Nature, 160, 87 (1947).

(12) Maruo, B. and Matsuhashi, M.: Oxidative phosphorylation in higher plant, Part 3, J. Agr. Chem. Soc. of Japan, 27, 433 (1953).

(13) Matchett, J. R., Leagault, R. R., Nimmo, C. C. and Natter, G. K.: Tartarates from grape wastes. Use of ion exchangers in acid carbonate cylcle, Ind. Eng. Chem., Ind. Ed., 36, 851 (1944).

(14) Mercer, W. A. and Vaughn, R. H.: The characteristics of some thermophilic, tartarate-fermenting anaerobes, J. Bact., 62, 27 (1951).

(15) Neuberg, C. and Schuchardt, W.: Über die Synthese der Phospho-d-weinsäure und ihre phosphatatische Spaltung, Enzymologia, 1, 39 (1936).

(16) Nomura, M.: The decomposition of $\mathrm{L}-(+)$-tartarate by the microorganism. Part 1, J. Agr. Chem. Soc. of Japan, 27, 46 (1953).

(17) Nomura, M.: The decomposition of L- $(+)$-tartarate by the microorganism. Part 2. On the anaerobic decomposition of L-tartarate in the presence of radioactive bicarbonate, J. Agr. Chem. Soc. of Japn, 27, 554 (1953).

(18) NomurA, M.: The decomposition of L-(+)-tartarate by the microorganism. Part 3. On the anaerobic metabolism of phosphoglycerate and oxalacetate as a possible intermediate in the anaerobic decomposition of tartarate by Pseudomonas incognita strain 3L, J. Agr. Chem. Soc. of Japan, 27, 860 (1953).

(19) SAKaguchI, K. and TADA, S.: On the formation of succinic acid by Bact. succinicum nov. sp. Zentl. f. Bakt., II Abt., 101, 341 (1940).

(20) Sprinson, D. B. and Chargaff, E.: On oxidative decarboxylation with perjodic acid, J. Biol. Chem., 164, 433 (1946). 
(21) TABAChinick, J. and VAUGHN, R. H.: Characteristics of tartarate-fermenting species of clostridium, J. Bact., 56, 435 (1948).

(22) Takahashi, H.: Studies on the decomposition of citrate by microorganisms. Part 4. On the fixation of carbon dioxide in Bact. succinicum, J. Agr. Chem. Soc. of Japan, 27, 832 (1953).

(23) Umbreit, W. W., Burris, R. H. and Stauffer, J. F.: Manometric Techniques and Tissue Metabolism, Burges Publishing Co., Minneapolis, (1949).

(24) Vaughn, R. H., Marsh, G. L., Stadtman, T. C. and Gantino, B. C.: Decomposition of tartarate by the coli-form bacteria, J. Bact., 52, 311 (1946).

(25) VeigA SAlles, J. B. and OchOA, S.: Biosynthesis of dicarboxylic acids by carbon dioxide fixation. II. Further study of the properties of the "malic" enzyme of pigeon liver, J. Biol. Chem. 187, 849 (1950).

(26) White, A. G. C., Krampitz, L. O. and Werkman, C. H.: Determination of biacetyl in tissue and bacterial filtrates, Arch. Biochem., 9, 229 (1946). 